\title{
Early art in the Urals: new research on the wooden sculpture from Shigir
}

Mikhail Zhilin ${ }^{1}$, Svetlana Savchenko ${ }^{2}$, Svend Hansen ${ }^{3}$, Karl-Uwe Heussner ${ }^{3} \&$ Thomas Terberger ${ }^{4, *}$

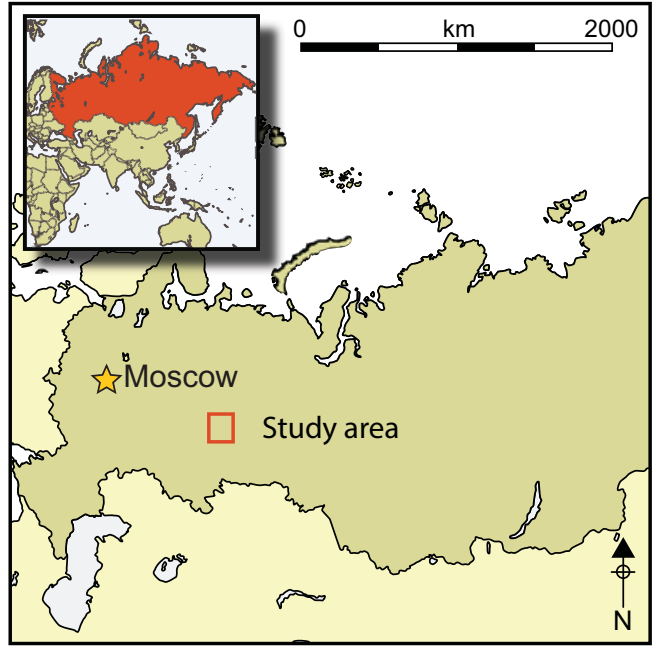

The carved wooden object uncovered from the Shigir peat bog in the Sverdlovsk region towards the end of the nineteenth century remains one of the oldest, known examples of monumental anthropomorphic sculpture from anywhere in the world. Recent application of new analytical techniques has led to the discovery of new imagery on its surface, and has pushed the date of the piece back to the earliest Holocene. The results of these recent analyses are placed here in the context of local and extra-local traditions of comparable prehistoric art. This discussion highlights the unique nature of the find and its significance for appreciating the complex symbolic world of Early Holocene huntergatherers.

Keywords: Russia, Urals, Early Mesolithic, art, sculpture, symbolism

\section{Introduction}

On 24 January 1894, a wooden sculpture was found during gold mining in the Shigir peat bog about $100 \mathrm{~km}$ north of Yekaterinburg, in the Middle Urals (see Figure S1 in the online supplementary material (OSM)). Today the area is flooded and no longer accessible (Figure S2). Ten wooden fragments were found about $4 \mathrm{~m}$ below ground level, and were first identified by Dmitri Ivanovich Lobanov as a sculpture approximately $2.8 \mathrm{~m}$ in height. Later, in 1914, Vladimir Yakovlevich Tolmachev reconstructed a much larger sculpture using all of the recovered fragments (Figures 1-2). Unfortunately, some of those fragments

\footnotetext{
Institute of Archaeology RAS, Dmitri Ulyanov Street 19, Moscow 117036, Russia

Sverdlovsk Regional Museum, Malysheva 46, Yekaterinburg, 620014, Russia

Svend Hansen, Eurasian-Department, German Archaeological Institute, Im Dol 2-6, 14195 Berlin, Germany

State Agency for Heritage Service of Lower Saxony, Scharnhorststrasse 1, 30175 Hannover, Germany

Author for correspondence (Email: thomas.terberger@nld.niedersachsen.de) 
have since been lost, but all the surviving pieces are on display in Sverdlovsk Regional Museum in Yekaterinburg.

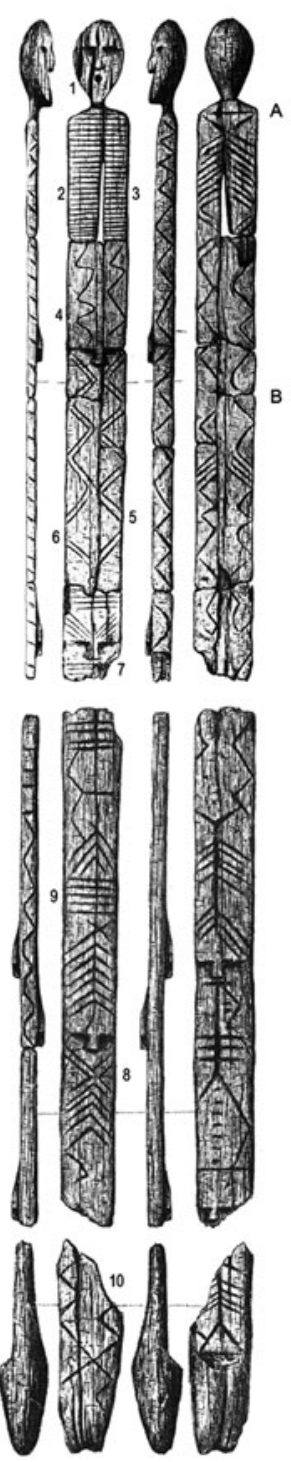

Figure 1. Drawing of the Shigir sculpture by Tolmachev (1914) and fragments 1-10. A) Position of new anthropomorphic face detected in 2014; B) position of new anthropomorphic face detected in 2003.
The unusual character of the sculpture made it difficult to assign a date from its typology, and indeed it remained undated for decades. In 1997, two large wooden samples were taken from the middle and the bottom part of the figure for conventional radiocarbon dating. Three measurements assigned it to the Boreal Mesolithic period c. 7900-7600 cal BC, making it the oldest wooden monumental sculpture in the world (Savchenko 1999; Lillie et al. 2005; Chairkina 2010).

In 2014, a new investigation was undertaken to provide: 1) a new and more detailed documentation of the figure by means of photographs and drawings; 2) to allow a morphological inspection of the wood, including the traces of working; 3) a systematic AMS dating program to deliver a more reliable date for the sculpture; and 4) to re-investigate the treering sequence. Investigations and sampling were performed in Yekaterinburg in June 2014. At the same time, a few decorated bone and antler objects from relevant sites were carefully sampled for AMS dating. Here we present the results of these analyses for the first time.

\section{Description}

As mentioned above, the sculpture did not survive in its entirety, and new descriptions have to take earlier reports into consideration. According to Tolmachev's reconstruction (1914), the figure was $5.3 \mathrm{~m}$ high, had a round sculptured head with a facial depiction, a plank-like body and a rounded, conical base (Figures 3-4, S3). The bottom part lacks any figurative details (Figure S4). Subsequently, a portion from the lower part—about $1.95 \mathrm{~m}$ long - was lost, but it is illustrated in Tolmachev's drawing (Figure 1). The preserved section of the figure on display in Sverdlovsk regional museum is $3.4 \mathrm{~m}$ tall (Figure S5). 
The body of the sculpture is covered by a deeply engraved ornamental pattern dominated by zig-zag lines. The flat surfaces also show carved faces, which belong to separate images.

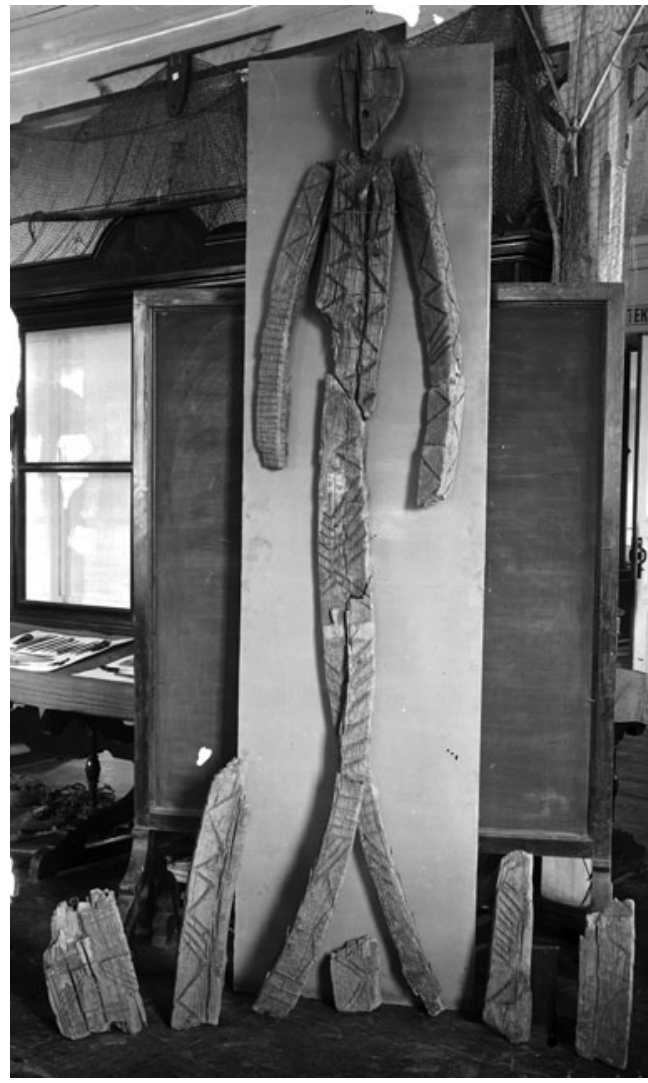

Figure 2. Photograph of the Shigir sculpture reconstructed by D. Lobanov (1890-1891), on display in this shape until 1914 (after Heikel 1894).

There are five such faces on Tolmachev's drawing: three on the front, and two on the back. In 2003, a sixth face was identified by Svetlana Savchenko on the back of the figure, in the middle of the preserved fragment (Figure 1B; Savchenko \& Zhilin 2004). It differs from the other faces, which display rectangular noses; for in this case, a branch protruding from the tree trunk was used for modelling the nose. This makes it more animal-like than the other depictions.

In 2014, during use-wear analysis of the figure, yet another new face was discovered by Svetlana Savchenko and Mikhail Zhilin in the upper part of the back (Figure 1A). In conclusion, eight figural depictions can now be identified, including the faces from the lost fragment attested by Tolmachev's drawing: the topmost figure with a round carved head, three flat faces on the front plus four flat faces on the back of the body. All of the faces appear distinctly individual.

The decorative elements of the Shigir figure may reflect encoded mythologies. The vertical placement of the faces could indicate the presence of an internal hierarchy among the images, or a sequence of events. Available ethnographic data provide only limited help in deciphering these carvings. Above all, however, the Shigir sculpture is unique within the early art of Eurasia and offers the potential for a better understanding of the spiritual world of early hunter-gatherer-fishers of the forest zone of Eurasia.

\section{Morphological and technological inspection of the wood}

The sculpture is made from a larch (Larix) tree. The trunk was split into two approximate halves, and a long plank was cut for the production of the anthropomorphic figure. During early growth, the branches of a larch tree are orientated upright, becoming horizontal or lower with age. In the case of the Shigir plank, the branches of the tree grew upright and their positions enable us to identify that the head of the sculpture was located at the upper (C) Antiquity Publications Ltd, 2018 

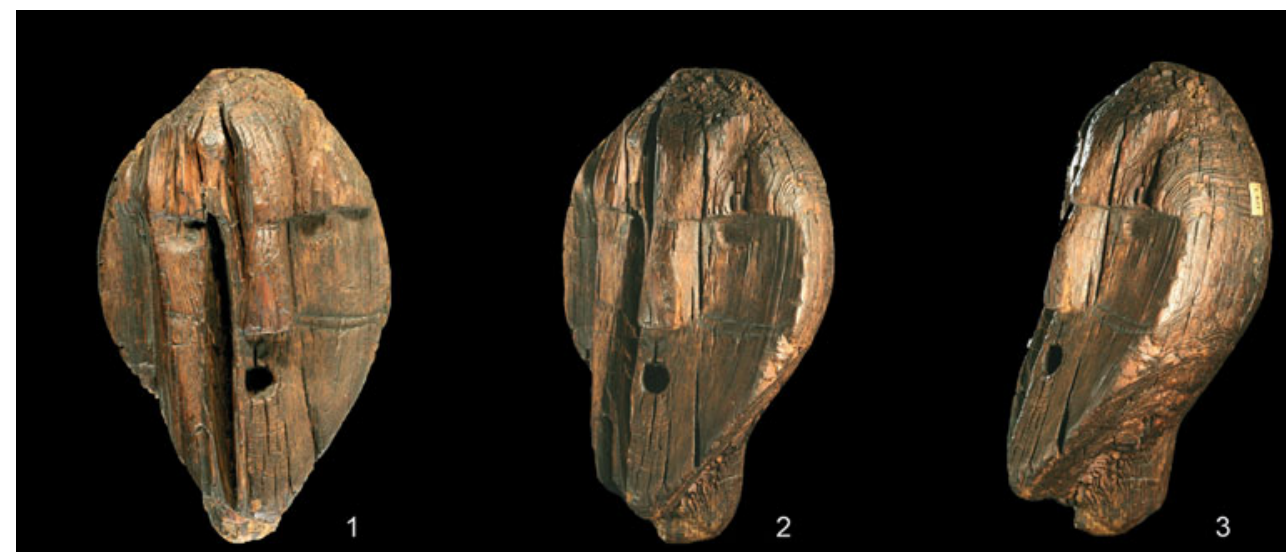

ปี

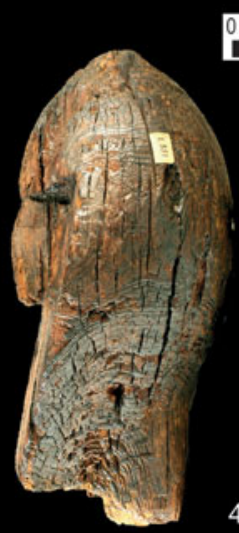

$10 \mathrm{~cm}$

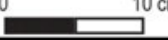

4
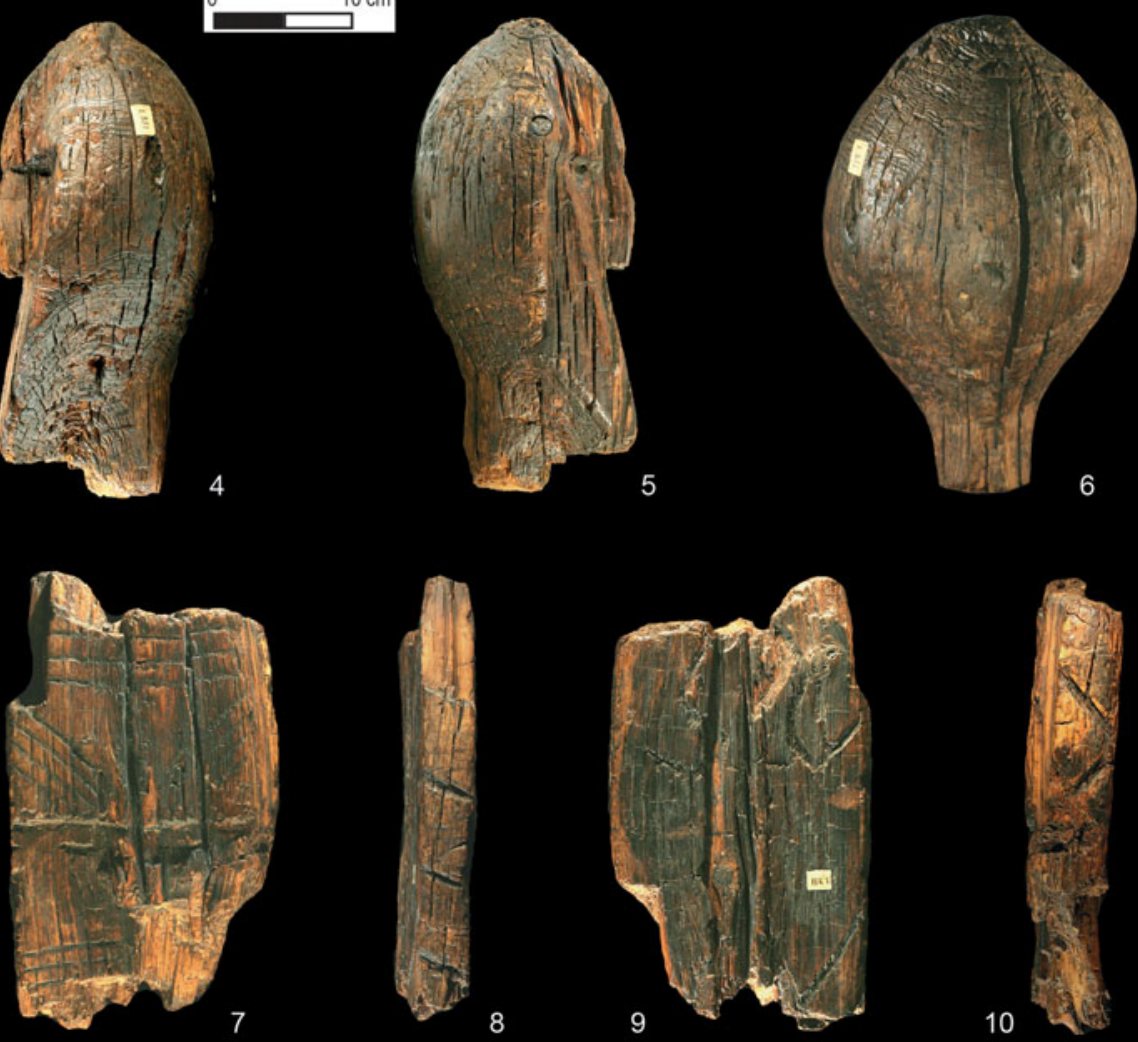

Figure 3 Head of the wooden Shigir sculpture and anthropomorphic face on fragment 7 (see Figure 1) (photograph by E.F. Tamplon).

end of the tree. The main part of the sculpture is relatively flat and is decorated on both sides (see above).

The tip of the base of the figure is crushed flat through pressure. This is probably due to the sculpture having stood upright for some time after manufacture, with its weight pressing

(C) Antiquity Publications Ltd, 2018 


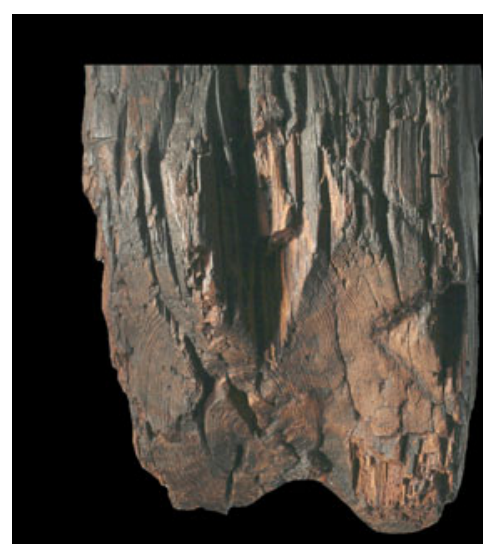

1

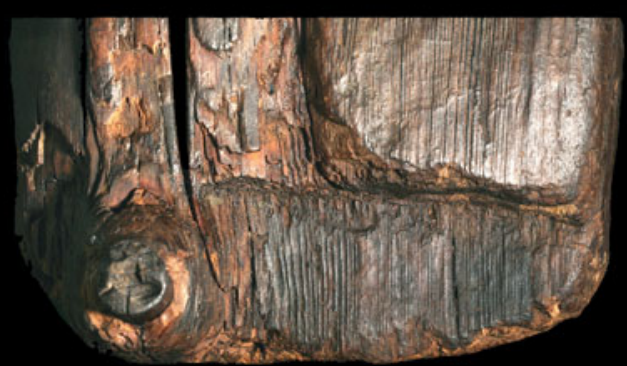

4

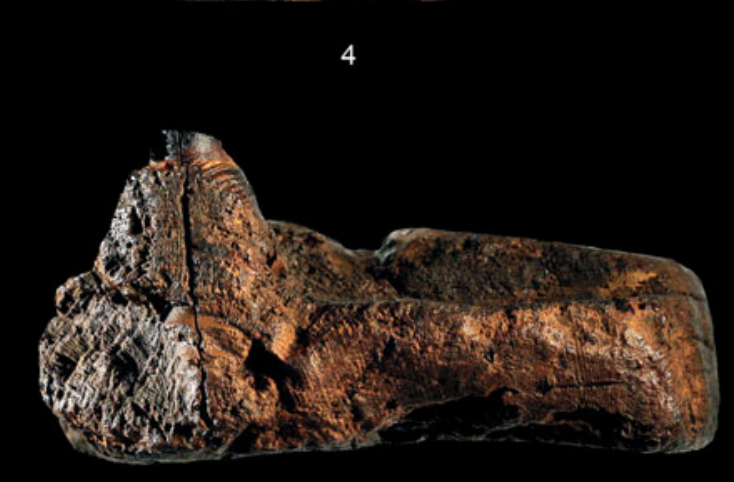

6

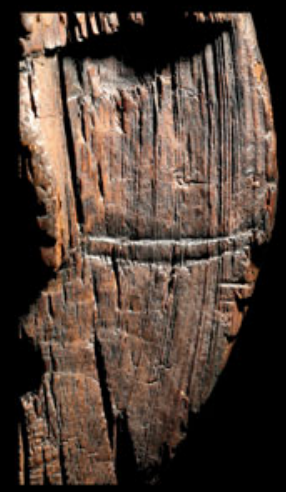

2

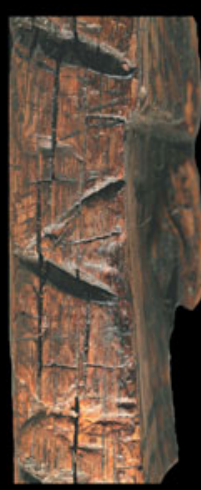

3

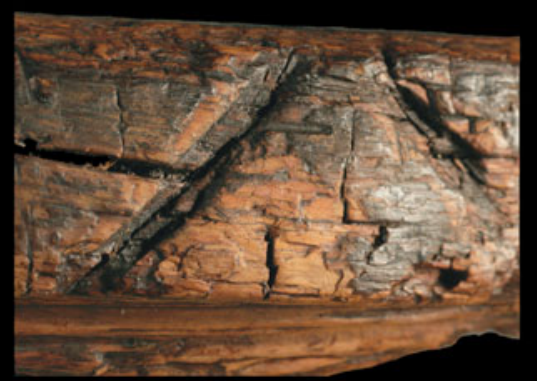

5

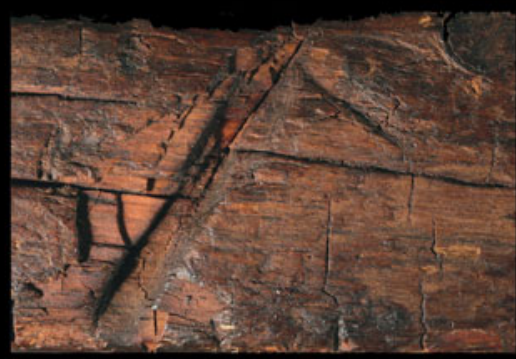

7

Figure 4. Details of the 'body' of the Shigir idol: 1) shows part of fragment 10 of the sculpture with traces of a broad polished adze visible on the bottom and obverse; 2-7) are all examples of traces made by narrow chisels, showing: 2) the face of the head; 3, 6 \& 7) different sides of fragment 7 (see Figure 1); and 4-5) showing the new face discovered in 2004 (photograph by E.F. Tamplon).

upon the tip of its base. This first caused cracks to appear, until later the sculpture collapsed. The well-preserved surface with very slight traces of abrasion suggests that it floated in water for only a limited period (of a maximum of about one year) before it was finally buried in the underlying sediment.

(C) Antiquity Publications Ltd, 2018 


\section{The head}

The head is three-dimensional, with narrow tree rings clearly visible on the top (Figure S3). These rings correspond closely with the narrow rings observed at the very bottom of the sculpture, which were selected for sampling. This suggests that all fragments of the sculpture originally belonged to the same tree trunk.

The upper part of the head shows lesions where wood fragments were chipped away. The nose is well sculpted but somewhat compressed, and to the left of it (frontal view) there is a deep, old crack. Double lines were carved below the nose and two incisions above it, with three lines on both sides of the head. The eyebrows gently slope down to the nose, and the eyes are cut into the surface. In both the left and right eyes, the pupil seems to be marked by greater depth, while the left eye is also marked by a knot in the wood where a branch was attached. Together, these features give the head a lifelike appearance. On the right cheek, cut marks, made probably by an adze, are visible, and the chin has clearly been tapered.

\section{The body}

The tree rings are visible on different fragments of the body, confirming that all of these belong to the same trunk. The zig-zag decoration on the outer surface was probably executed in the area of the outermost tree rings (Waldkante). Tree rings can be identified on the surface of the figure and in various carved cuts. All cuts upon the body were made with sharp implements, leaving no compressed wooden tissue from the carving process, suggesting that the sculpture was made of green wood.

Pieces 3 and 4 (Figure 1) fit well together, and the visible breakage between them is clearly modern, but the origin and character of the break in the centre of piece 4 is less clear. A carved anthropomorphic face recorded in Tolmachev's drawing of pieces 4 and 6 is no longer visible. This part has been restored using wax. In contrast, the human face on piece 7 is easily identified, showing clear cut marks. The loss of some fragments of the figure means that the 'body' cannot be reconstructed in total. A modern cutting made for analytical purposes is clearly visible at the base of the sculpture.

\section{Traces and tools}

The surface of the figure shows repeated evidence of working. The characteristic traces were probably caused by a polished stone adze and two or three different types of polished stone chisel. The adze marks are visible on the bottom part of the sculpture in the shape of long broad scars with even flat surfaces, and without the striations and grooves that would be left by an unpolished adze (Figure 4.1). Traces left by the chisels are also flat and sharp, and are visible, for example, on the cheeks of the idol and in some of the decorative lines (Figures $3.1-3,4.2,5 \& 7)$. Differences in the size of the cut marks indicate the use of two or three different chisels. Such sharp traces also support the conclusion that the carving was made in green wood.

Polished stone adzes have been recovered from layer IV of the Beregovaya 2 site situated at the western border of the city of Nizhny Tagil (Figure S1), dated to $c .8200-7500 \mathrm{cal}$ BC (c. 9000-8400 BP). In layer V of the same site, dated to the early Preboreal $(c .9300 \mathrm{cal}$ 
BC/9800 BP; Zhilin et al. 2014, 2017), preforms and flakes from the manufacture of such tools were identified. One of these flakes with a polished dorsal surface probably derives from a polished wood-cutting tool. A decorated and perforated polished artefact of nonsiliceous material was discovered in the same layer. There is, in short, clear evidence that wood-working tools of polished stone were in use in the Urals at the time the figure was carved (Zhilin 2007, 2010; Hartz et al. 2010).

\section{Tree-ring sequence}

Of 159 tree rings, only 137 could be measured due to the poor preservation of the outermost 22 (Figure S6). The innermost 18 rings are clearly narrower than the outer rings. This is an indication of difficult conditions during the early growth of the tree, probably caused by pressure from neighbouring trees. After about 20 years, the tree had established itself, and a relatively stable growth phase followed for another 60 years. Growth rates became unstable with strong declines over the next 30 years, probably due to repeated phases of poor climate. The average annual growth rate of $2.49 \mathrm{~mm}$ is much lower than that of today. The RUSS004-chronology (Shiyatov n.d.) from the sub-alpine area of the southern Urals is characterised by an average growth rate of $9.89 \mathrm{~mm}$ per annum. The modern values also demonstrate a higher variability and standard deviation as well. A more detailed interpretation of the sequence will only be possible with more information on the local conditions and through comparison with sequences from other trees of that time; a single sample can be influenced by highly localised conditions and events.

\section{Dating of the object}

\section{Material and methods}

The development of AMS dating and new pretreatment methods enabled the new approach taken to dating the Shigir figure in 2014. The larch wood of the sculpture was carefully sampled a few centimetres above the earlier cut; a narrow transect of the tree-ring sequence was then carefully cleaned with a razor blade. The tree rings were marked with chalk after sampling to improve their contrast (Figure 5). They were then recorded using a stereomicroscope.

Sampling for AMS dating was done on the basis of the counted sequence. Sample numbers 1-4 were taken off for every 50 tree rings (Figure 5; Table 1). Every sample consisted of four tree rings. As the sculpture was made from a split plank, sample 1 is located at the centre of the former tree (Markbereich), while sample 4 was situated closest to the outermost tree rings. Three further samples (5-7) were taken between samples 1 and 2, 2 and 3, and 3 and 4 .

As the figure was discovered some 120 years ago, we anticipate that it will have undergone repeated restoration processes with the help of different materials and consolidants. Sampling of the parts affected by these processes was avoided as far as possible. All samples were put in glass tubes and later submitted to the Klaus Tschira-Laboratory at the Curt-Engelhorn-Centre in Mannheim. Processing and pretreatment of the samples was conducted according to modern standards. First the samples were pretreated with acid-wash (C) Antiquity Publications Ltd, 2018 


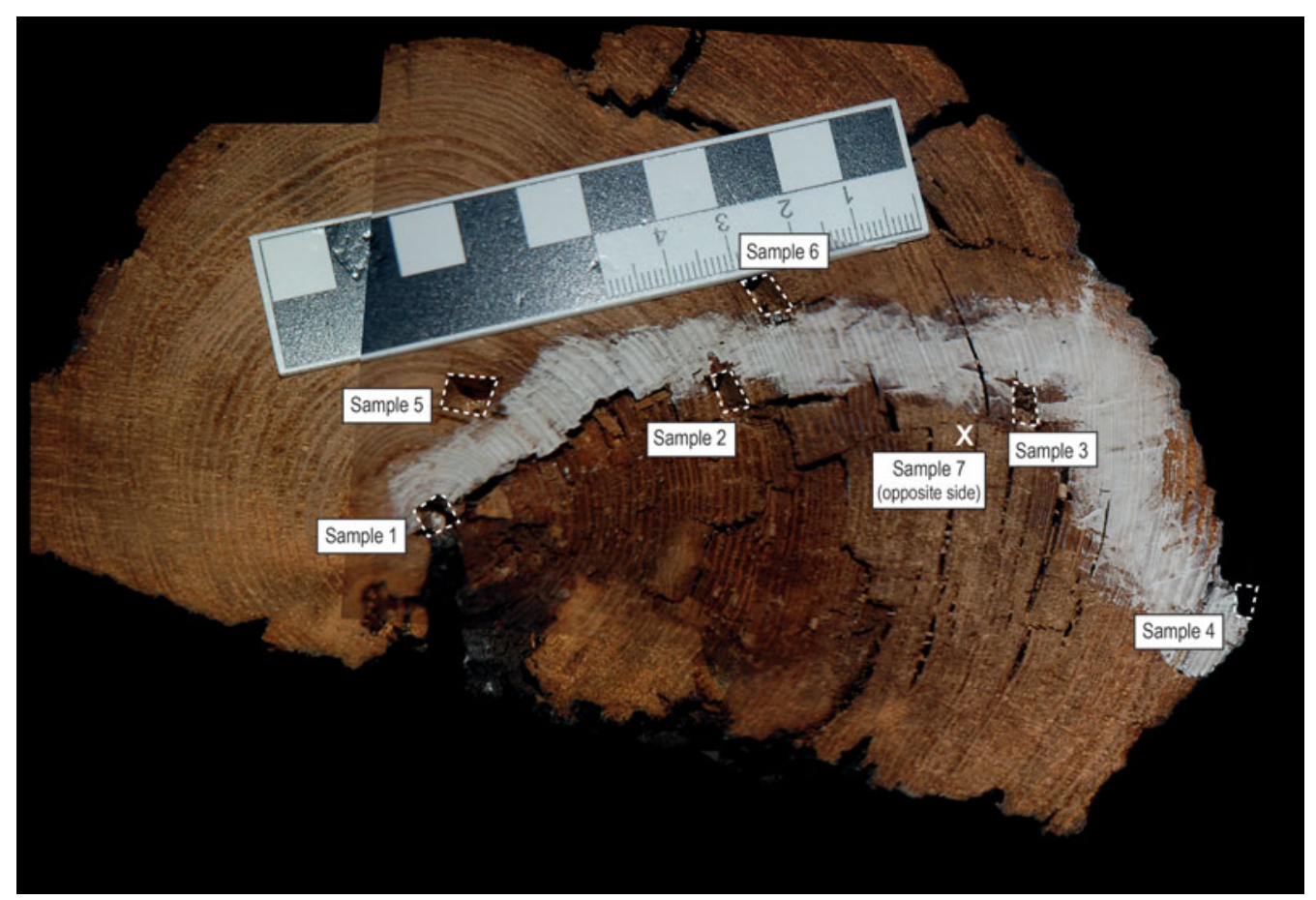

Figure 5. Position of the samples in the tree-ring sequence relative to chalk markings (photograph/graphic by T. Terberger).

and chloroform to remove consolidants. Subsequently, the ABA-method (acid/base/acid) using $\mathrm{HCl}, \mathrm{NaOH}$ and $\mathrm{HCl}$ was applied, followed by bleaching with $\mathrm{NaClO}_{2}$ to extract the cellulose. The cellulose was combusted in an element analyser, and $\mathrm{CO}_{2}$ was catalytically reduced to graphite. The measurement of the samples was performed by a MICADASAccelerator.

\section{AMS results}

All samples were successfully measured, but the results show considerable variation (Table 1). Samples 1 and 4 correspond well with each other and provide the latest dates of the series, between $c$. 7000 and 6600 cal BC (MAN-21895: 7930土36 BP; MAN-21898: $7864 \pm 36 \mathrm{BP})$. These two results suggest a date in the early Atlantic period.

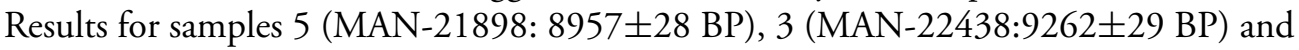
7 (MAN-21897: 9450 $\pm 40 \mathrm{BP}$ ) from the inner part of the sculpture are considerably older (c. 9000-8000 cal BC), supporting a Preboreal to early Boreal date. Results for samples

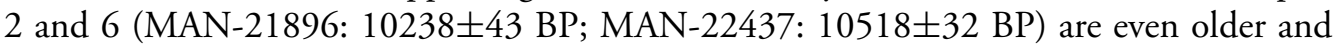
would assign the piece to a period close to the end of the Late Palaeolithic (c. 10 500-10 000 cal BC).

The results of these seven new AMS dates confirm the Stone Age attribution, but the difference of up to $c .3000$ years requires explanation. The sculpture has been repeatedly restored since it was found. Macroscopic inspection confirmed the use of wax for the 
Table 1. Radiocarbon dates of finds from the Shigir collection and the site of Bergovaya 2. For the position of the samples, see Figure 5. Calibration of radiocarbon dates was performed with OxCal v4.2.3. on the basis of IntCal 13 and dates are given at the 95\% confidence level (Bronk Ramsey 2009;

Reimer et al. 2013).

華

\begin{tabular}{lllllll}
\hline Laboratory no. & ID & Sample material & Location of sample & ${ }^{14} \mathrm{C}$-age BP & Date range cal $\mathrm{BC}$ & ${ }^{13} \mathrm{C}$ in $\% 0$
\end{tabular}

Shigir sculpture, conventional dates

GIN $9467 / 1$

Mos $9467 / 2$

larch wood

larch wood

larch wood

$8680 \pm 140$

$8750 \pm 60$

$8211-7526$

Le 5303

$8620 \pm 70$

7933-7529

\section{Shigir sculpture, AMS dates}

MAN $21895 \quad$ Shigir sample

MAN $22436 \quad$ Shigir sample 5

MAN $21896 \quad$ Shigir sample 2

MAN 22437 Shigir sample 6

MAN $22438 \quad$ Shigir sample 7

MAN $21897 \quad$ Shigir sample 3

larch wood

larch wood

larch wood

larch wood

larch wood

Shigir sample 4

larch wood

larch wood

tree ring 1-4

tree ring 28-22

tree ring $48-52$

tree ring 58-62

tree ring $88-92$

tree ring $98-102$

tree ring 148-152

$\begin{array}{ccc}7930 \pm 36 & 7030-6683 & -26.1 \\ 8957 \pm 28 & 8270-7980 & -21.9 \\ 10238 \pm 43 & 10183-9825 & -29.6 \\ 10518 \pm 32 & 10621-10457 & -22.1 \\ 9262 \pm 29 & 8606-8349 & -21.8 \\ 9450 \pm 40 & 9108-8623 & -31.6 \\ 7864 \pm 34 & 6825-6607 & -25.7\end{array}$

$9698 \pm 36$

$9267-8929$

$-24.2$

6.0 C/M 8985, AW 1898

elk antler

$8399 \pm 40$

$7551-7355$

$-20.9$ 


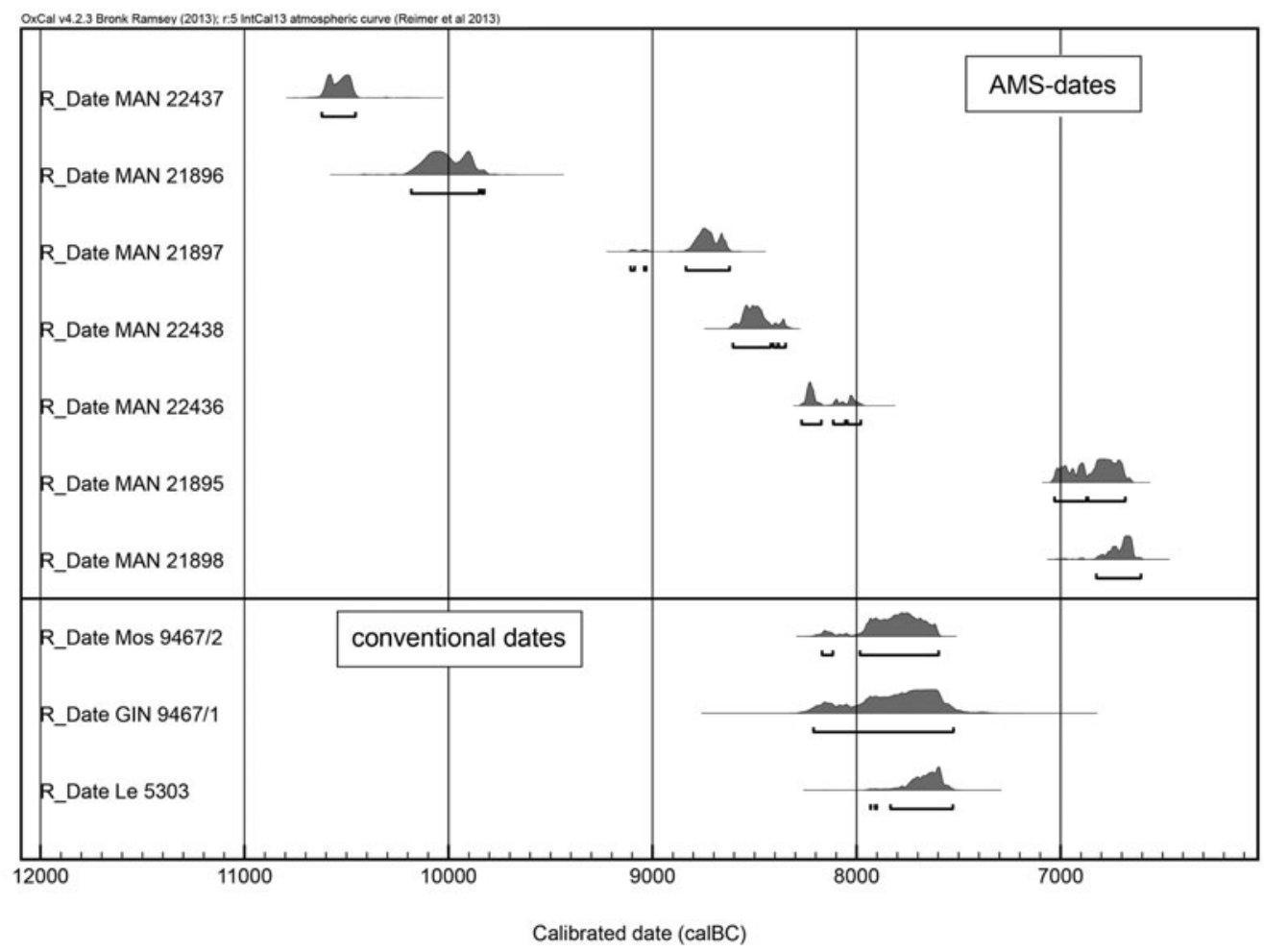

Figure 6. Calibrated AMS dates of the idol (OxCal v4.2.3 using the IntCal13 calibration curve; Bronk Ramsey 2009; Reimer et al. 2013).

conservation, repair and reconstruction of damage incurred during the late nineteenth/early twentieth century. In 1997 the wooden sculpture was treated by conservator Olga Anatolyevna Tuberozova of the Sverdlovsk Regional Museum. Cavities caused by sampling for the initial series of radiocarbon dates were filled with finely ground wood pigment mixed with 10 per cent Butyl acrylate dissolved in acetone and white spirit. The outer surface layer of the figure was stabilised with Butyl acrylate dissolved in acetone and white spirit; the concentration was progressively increased from 3 to 10 per cent. The effects of this treatment would be most marked on the outer surface. Despite careful sample pretreatment, it is possible that the consolidants were not completely removed.

In recognition of this we expect that AMS samples 1 and 4, taken closest to the surface (Figure 5), have a higher probability of being affected by such treatments (see Chairkina et al. 2013). This is corroborated by a strong correlation between the distance of the sample from the surface of the sculpture and the AMS results (Figure S7): AMS dates are increasingly older towards the inner part of the sculpture. Samples 2 and 6 are therefore the most reliable, suggesting that the find should be dated to $c .10200 \mathrm{cal} \mathrm{BC} \mathrm{(c.} 10200 \mathrm{BP}$; Figure 6 \& Table 1 ).

In the late 1990s, an earlier attempt at dating the Shigir figure by the conventional radiocarbon technique was undertaken. Sample material was obtained from cuts to the

(C) Antiquity Publications Ltd, 2018 
bottom and middle of the object prior to Butyl acrylate treatment. Three conventional dates were obtained that correspond well with each other (Table 1), dating the sculpture to c. 7900-7600 cal BC (c. 8700 BP; Boreal period). The homogeneous results of the three earlier dates can be explained by the large samples necessary for conventional radiocarbon dating. Wood from the inner and the outer parts of the tree were probably mixed, giving a mean value for the sample material.

The new results are more reliable and date the Shigir sculpture to an earlier period. Samples 2 and 6 come from the innermost part of the tree, representing its early growth. It was felled around 160 years later. The radiocarbon dates suggest a date of $c .10200 \mathrm{BP}$ for the carving of the sculpture, close to the transition from the Younger Dryas to the Preboreal (c. $9600 \mathrm{cal} \mathrm{BC)}$. A strong wiggle in the calibration curve at the transition to the Holocene makes attempts at more accurate dating in this time period almost impossible (Figure 6).

Pollen diagrams from the Gorbunovo peat bog (close to the site of Bergevoaya 2; (Figure S1)) and Shigir peat bog demonstrate the presence of larch and pine (Pinus) during the late Younger Dryas, with up to 12 per cent arboreal pollen, increasing during the Preboreal. Sparse larch forests against a background of large open spaces have been reconstructed from the pollen cores of level V (the bottom layer) of the Beregovaya 2 peat bog (Zaretskaya $e t$ al. 2014). The tree-ring sequence of the Shigir sculpture is consistent with this in showing very limited growing conditions.

According to early reports, the sculpture was found in peat deposits (Tolmachev 1914), and this is confirmed by peat residue in crevices and old cracks of the sculpture. This supports the suggested dating of the sculpture and its deposition to the period when peat formations started to develop. In conclusion, we propose a dating of the sculpture to c. $9600 \mathrm{cal} \mathrm{BC.}$

\section{Decorated Mesolithic antler from the Shigir collection}

The Shigir peat bog is famous for numerous organic prehistoric finds collected during many years of gold mining activities. Among them are bone points and slotted bone daggers, which can be assigned to the Stone Age on typological grounds. In 1887 a decorated elk antler $(0.24 \mathrm{~m}$ long and $0.06 \mathrm{~m}$ wide) with a perforation, figurative carving and highly polished surface was collected as a stray find. The perforated end is engraved, while the antler beam at the opposite end is carved into an animal head (Figures $7 \&$ S8-9). Two small knobs close to the perforation indicate ears or eyes, while the muzzle is engraved with two lines on each side. The muzzle is emphasised by a series of triangular incisions, which perhaps represent teeth. An incised line is present on the top, while below the muzzle, simple lines of decoration are present. The ears and the shape of the long snout are reminiscent of a wolf or dog, while the two shallow nasal impressions are more suggestive of a wild boar. The mixture of elements could therefore represent a fantasy animal or mythical creature (Zhilin 2010).

In June 2014, the antler was AMS dated in Aarhus and assigned to $c .9100$ cal BC (AAR24229; Table 1), making it another example of elaborate, figurative early Preboreal art.

(C) Antiquity Publications Ltd, 2018 

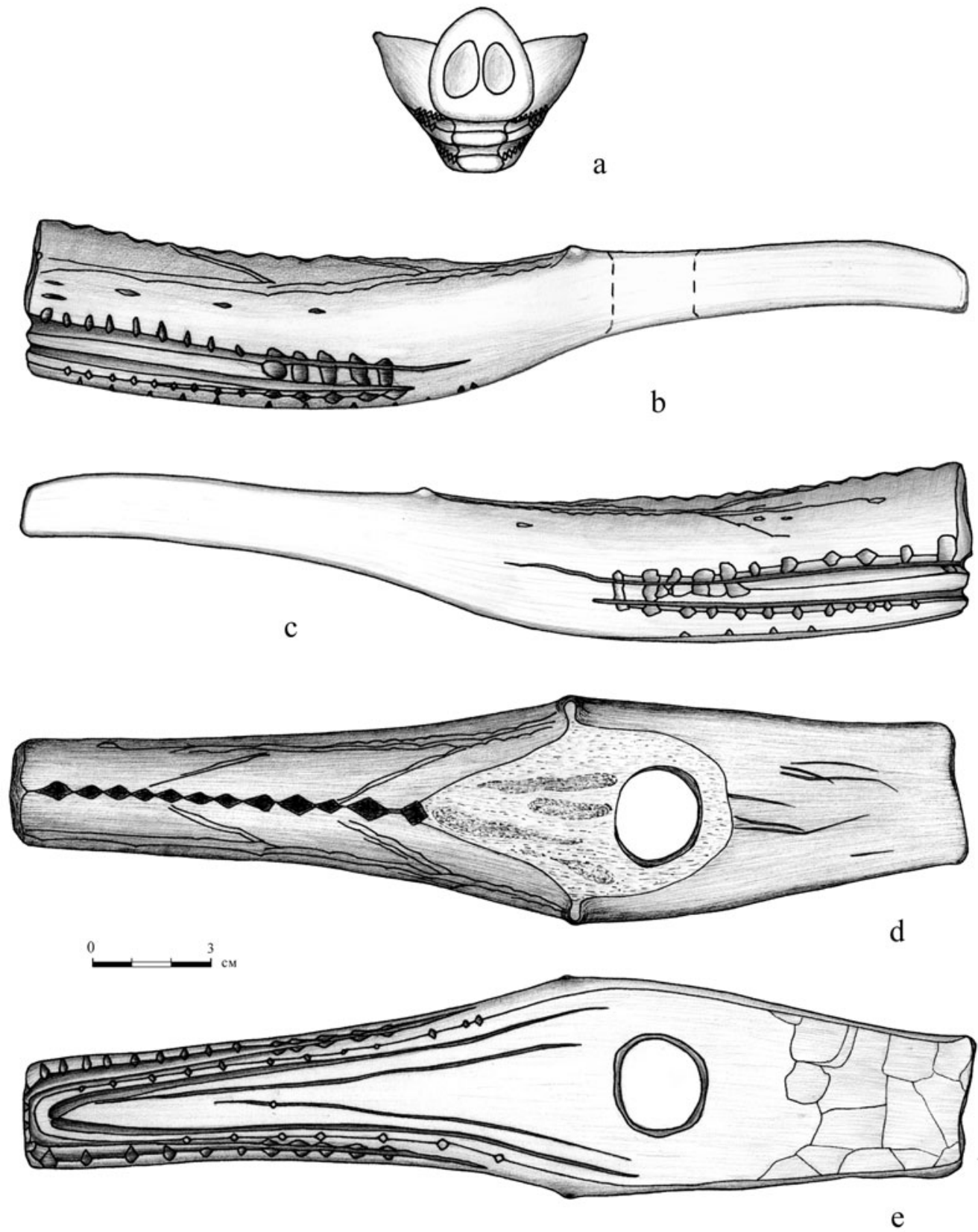

Figure 7. Drawing of decorated antler object from Shigir collection (after Zhilin 2010).

\section{Mesolithic art from Beregovaya 2}

Another piece of Mesolithic art was excavated at the multi-layer peat bog site Beregovaya 2, located about $150 \mathrm{~km}$ north/north-west of Yekaterinburg (Zhilin \& Savchenko 2010). A 
small animal head (bear(?); Figure 8), probably carved from elk (Alces alces) antler (identified by Pavel Kosintsev), was found in layer III, which is dated to the late Boreal according to its context (Zhilin et al. 2014). The face of the head uses the natural surface
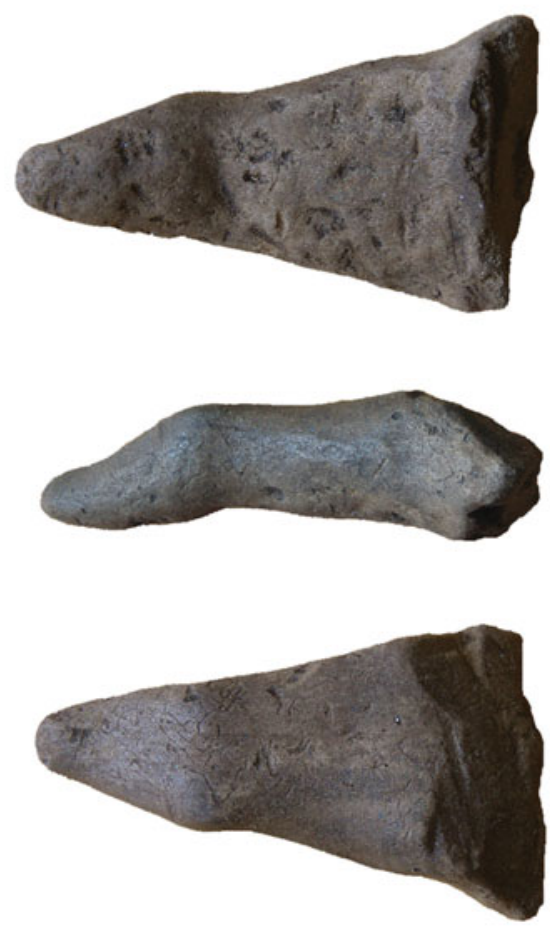

Figure 8. Animal head made of antler from the site of Beregovaya 2 (photograph by T. Terberger). of the antler, while the bottom of the head displays traces of shaping by a stone burin, smoothed by fine grinding and polishing. The age inferred from the stratigraphy is corroborated by a new AMS date of $c .7500$ cal BC (AAR-24230; Table 1).

\section{Discussion}

The sculpture and engraved antler pieces from Shighir and Beregovaya 2 (layer III) play an important role in the discussion of Early Mesolithic art in the Urals. A series of seven AMS dates give a probable early Preboreal date for the famous Shigir sculpture. Morphological observations suggest that it was made from a freshly felled larch tree. The object, which was probably originally $5.3 \mathrm{~m}$ long, is famous for its monumental character and unusual anthropomorphic depictions, including a large sculpted head on the top, and a series of carved faces on the body as well as complex ornamentation.

A perforated antler with outstanding decoration, probably showing the head of a canine, wild boar or some fantastic beast, belongs to approximately the same period. This animalheaded staff further supports the presence of a surprisingly rich and varied body of Early Mesolithic art in the Transurals, including elaborate figures of humans and animals. A small antler bear head from Beregovaya 2 dates to several hundred years later, and testifies to an enduring tradition of figurative art in this region throughout the Mesolithic.

Knowledge of archaeological sites of the Late Glacial and the Early Holocene is still very limited in the Urals (Serikov 2000; Zhilin et al. 2014: 165). Kapova Cave, located about $500 \mathrm{~km}$ south-west of Yekaterinburg in the southern Urals, is well known for red-painted parietal art depicting mammoths, woolly rhinos and horses, which probably date to the Late Upper Palaeolithic. In Ignatievskaya Cave, $150 \mathrm{~km}$ to the north, more than 30 groups of red and black cave paintings have also been assigned to the Late Upper Palaeolithic (Petrin \& Širokov 1995; Ščelinskij \& Širokov 1999). Both sites demonstrate a tradition of cave art in the southern Transurals towards the end of the Late Glacial. The paintings show general similarities to contemporaneous cave art from France and Spain, but are generally smaller in size. Within Ignatievskaya Cave, however, there are depictions of an ungulate (C) Antiquity Publications Ltd, 2018 


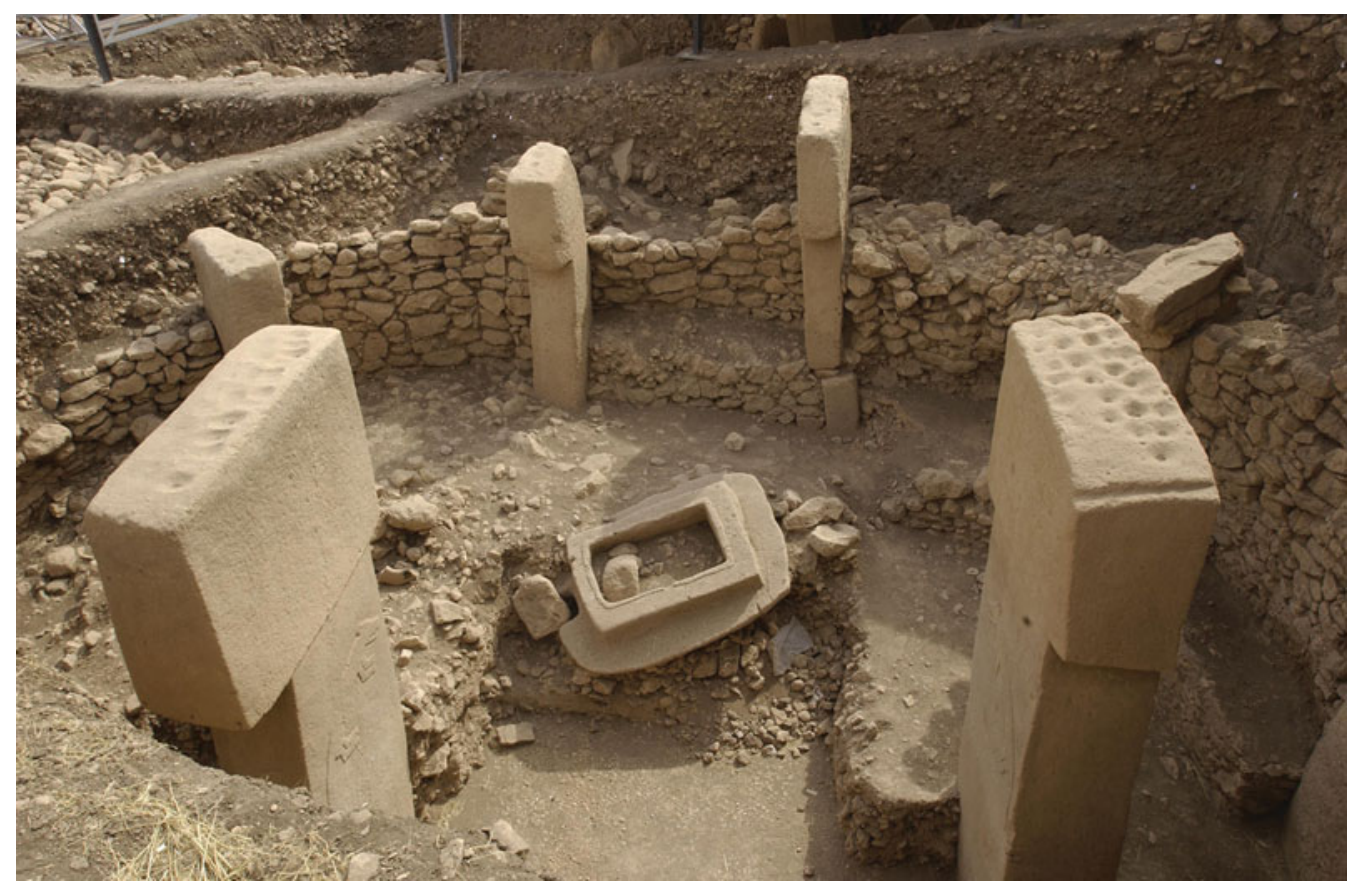

Figure 9. Göbekli Tepe, south-eastern Turkey. Anthropomorphic steleae (photograph courtesy of DAI/German Archaeological Institute).

approximately $2.3 \mathrm{~m}$ long, painted red and of an abstract female human figure around $1.3 \mathrm{~m}$ tall. In conclusion, Late Upper Palaeolithic art in the Transurals shows a considerable variability of motifs, sometimes including larger figures.

The discovery of animal paintings in Coliboaia Cave in Romania (Ghemis et al. 2011) confirmed the presence of Upper Palaeolithic cave art in eastern Central Europe, and there is evidence for a rich body of portable art from (Late) Upper Palaeolithic sites in Eastern Europe and also farther east (e.g. Kozłowski 1992; Abramova 1995; Hansen 2007).

The limited number of Final Palaeolithic to Early Mesolithic sites in the Urals does not provide material comparable to the two outstanding finds from the Shigir peat bog. In the Upper Volga region, some $1700 \mathrm{~km}$ to the west, there is evidence of decorated Mesolithic objects of bone and antler from sites such as Zamostje 2 and Ivanovskoje 7, including carved elk figures and an unknown animal head, but these finds are considerably later and date to the Late Mesolithic (Atlantic period, seventh millennium cal BC) (Zhilin 2010).

In Central and Western Europe there are a few Late Palaeolithic finds (c. 12 000-9600 cal BC), which document the presence of portable art of Late Upper Palaeolithic tradition. Small elk figurines made of amber along with objects with geometric engravings or traces of paint date to the Allerød (Veil \& Terberger 2009). Very few decorated objects, however, including isolated anthropomorphic engravings and objects with geometric decoration, are known from the Younger Dryas. The latest Ice Age cave art mostly comprises engravings, which are known in France, southern Italy and probably also in Britain (e.g. d'Errico 1994; Bahn \& Pettitt 2009; Tusa et al. 2013). 


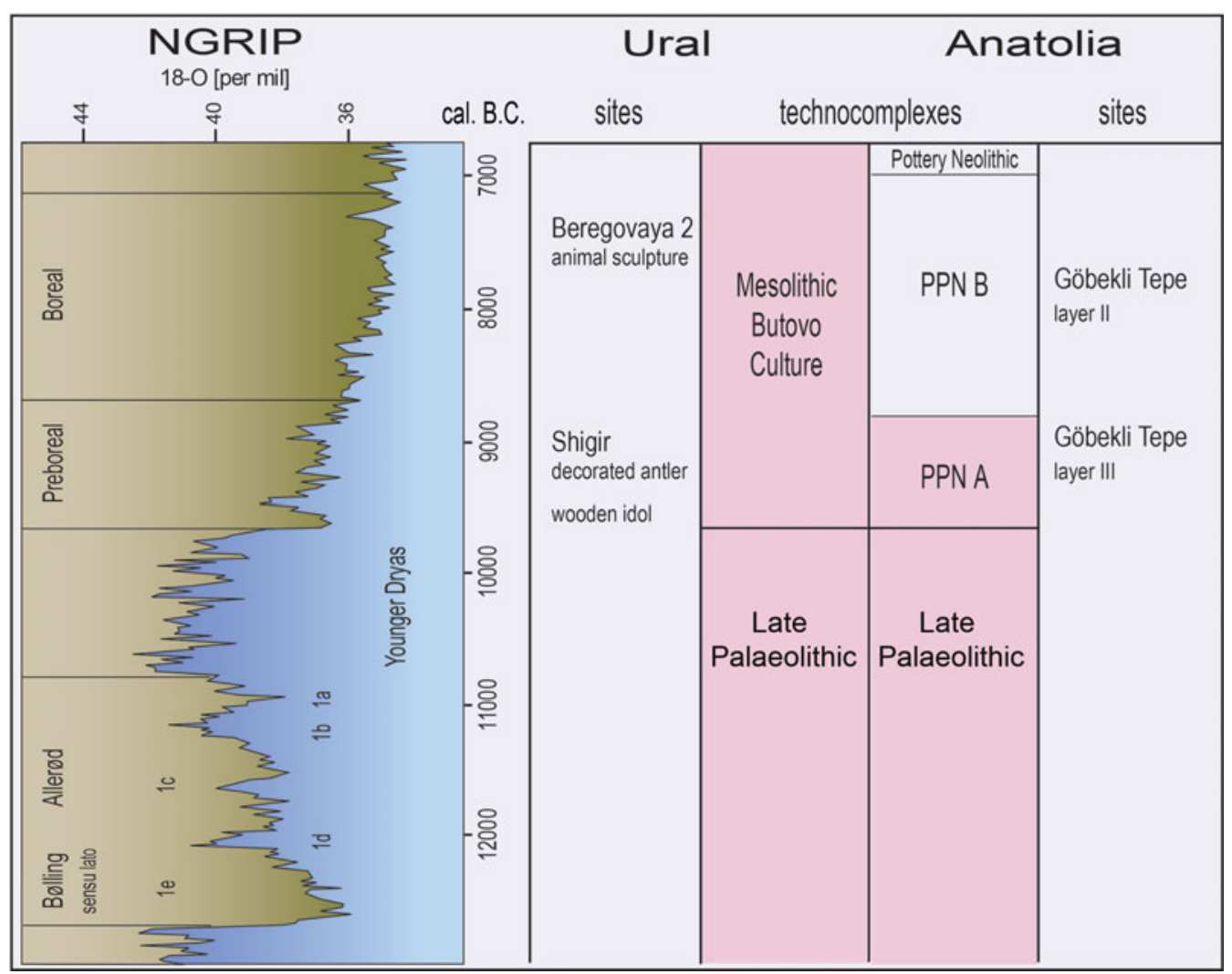

Figure 10. Chrono-stratigraphic context of Early Holocene art.

Engravings of small, schematic, anthropomorphic figures and animals on bone and antler objects are a rare feature of the Maglemosian in the western Baltic (e.g. Płonka 2003; Kabacinski et al. 2011). This has nothing in common with the earlier style of anthropomorphic sculptures or facial depictions, and there are no decorated wooden objects or animal representations comparable to those from Shigir.

In the Levant and neighbouring regions, however, a considerable and multifaceted body of art has been documented from Late Palaeolithic (c. 12000-9600 cal BC) and Early Holocene sites. Late Palaeolithic techno-complexes such as the Natufian provide repeated examples of stone figurines including elaborate representations of animals and sometimes humans (Hansen 2007). During the Early Holocene and the Pre-Pottery Neolithic, representations of art and architecture became more complex. In south-eastern Anatolia, stone sculptures depicting various animals including birds and snakes, and anthropomorphic figures, were recovered from Pre Pottery Neolithic A (PPNA) Nevalı Çori (Hansen 2007; Hauptmann \& Schmidt 2007).

The most prominent examples of PPNA art were excavated at the site of Göbekli Tepe some kilometres farther south-west. The site is famous for its circular stone structures with pillars up to $4 \mathrm{~m}$ tall (Figures 8-9 \& S10). The T-shaped stelae can be identified as anthropomorphic stone sculptures, in some cases with carvings of gazelles, foxes, birds and snakes (C) Antiquity Publications Ltd, 2018 
(Schmidt 2007). The circular structures are interpreted as places for ritual. Göbekli Tepe also provided some examples of portable art dating between the tenth and eighth millennia cal BC (Dietrich et al. 2012). There is no doubt that the large stone stelae at Göbekli Tepe were erected during the early phase of its use (c. 9600-8800 cal BC), when some 20 circular enclosures were used for ritual purposes by late hunter-gatherers (Dietrich et al. 2012).

The earliest monumental human figure from this region is represented by the stone sculpture $(1.93 \mathrm{~m}$ tall) found at Urfa. It shows a man wearing a necklace with his hands held to his front at groin height (Hauptmann 2003; Hauptmann \& Schmidt 2007; Hansen 2014). The pillar-like basis of the sculpture leaves no doubt that it was displayed standing upright.

South-east Anatolia, with sites such as Nevalı Çori and Göbekli Tepe, is therefore the only region besides the Urals where we find evidence for monumental anthropomorphic sculptures and animal representations of Early Holocene date (Figure 10). The finds from the Shigir peat bog indicate the existence of an impressive, elaborate tradition of art contemporaneous with that of south-east Anatolia. Early Holocene hunter-gatherers clearly inhabited a symbolic world with richer and more complex forms of artistic expression than was previously believed.

\section{Supplementary material}

To view supplementary material for this article, please visit https://doi.org/10.15184/aqy. 2018.48

\section{References}

Aвramova, Z.A. 1995. L'art paléolithique d'Europe orientale et de Sibérie. Grenoble: Jérôme Millon.

Bahn, P. \& P.B. Ретtitt (ed.). 2009. Britain's oldest art: the Ice Age cave art of Creswell Crags. Swindon: English Heritage.

Bronk Ramsey, C. 2009. Bayesian analysis of radiocarbon dates. Radiocarbon 51: 337-60. https://doi.org/10.2458/azu_js_rc.51.3494

Chairkina, N.M. 2010. Peat-bog sites in the Trans-Urals. Archaeology, Ethnology and Anthropology of Eurasia 38: 85-92. https://doi.org/10.1016/j.aeae.2011.02.007

Chairkina, N.M., Y.V. Kuzmin \& G.S. Burr. 2013. Chronology of the perishables: first AMS ${ }^{14} \mathrm{C}$ dates of wooden artefacts from Aeneolithic-Bronze Age waterlogged sites in the Trans-Urals, Russia. Antiquity 87: 418-29. https://doi.org/10.1017/S0003598X00049036

D'ERrico, F. 1994. L'art grave azilien de la technique à la signification (Gallia Préhistoire supplement 31). Paris: CNRS.

Dietrich, O., M. Heun, J. Notroff, K. Schmidt $\&$ M. ZARnKow. 2012. The role of cult and feasting in the emergence of Neolithic communities: new evidence from Göbekli Tepe, south-eastern Turkey. Antiquity 86: 674-95.

https://doi.org/10.1017/S0003598X00047840
Ghemiş, C., J. Clottes, B. Gély \& F. Prud'homme. 2011. An exceptional archaeological discovery: the 'Art Gallery' in Coliboaia Cave, Apuseni Mountains, Romania. Acta Archaeologica Carpathica 46: 5-18.

Hansen, S. 2007. Bilder vom Menschen der Steinzeit (Archäologie in Eurasien 20). Mainz: Philipp von Zabern.

- 2014. Neolithic figurines in Anatolia, in M. Özdoğan, N. Başgelen \& P. Kuniholm (ed.) The Neolithic in Turkey 6: 265-92. Istanbul: Arkeoloji ve Sanat.

Hartz, S., T. Terberger \& M. Zhilin. 2010. New AMS-dates for the Upper Volga Mesolithic and the origin of microblade technology in Europe. Quartär 57: 155-69.

Hauptmann, H. 2003. Eine frühneolithische Kultfigur aus Urfa, in M. Özdoğan, H. Hauptmann \& N. Başgelen (ed.) From village to cities: early villages in the Near East: 623-36. Istanbul: Arkeoloji ve Sanat.

Hauptmann, H. \& K. Schmidt. 2007. Anatolien vor 12.000 Jahren. Die Skulpturen des Frühneolithikums, in Badisches Landesmuseum Karlsruhe (ed.) Vor 12.000 Jahren in Anatolien. Die ältesten Monumente der Menschheit: 67-73. Karlsruhe: Konrad Theiss.

(C) Antiquity Publications Ltd, 2018 
Heikel, A. 1894. Antiquites de la Siberie occidentale (Memoires de la Societe finno-ougrienne VI). Helsingfors: Société de littérature finnoise.

Kabacinski, J., S. Hartz \& T. Terberger. 2011. Elks in the Early Stone Age art of the northern lowlands. Prähistorische Zeitschrift 86: 151-64. https://doi.org/10.1515/pz.2011.010

KozŁowski, J.K. 1992. L'art de la préhistoire en Europe orientale. Paris: CNRS.

Lillie, M., M. Zhilin, S. Savchenko \& M. TaYlor. 2005. Carpentry dates back to Mesolithic. Antiquity Project Gallery 79(305). Available at: http://www.antiquity.ac.uk/projgall/lillie/ (accessed 6 September 2017).

Petrin, V.I. \& V.N. Širokov. 1995. Die Ignatievka-Höhle (Ural). Jungpaläolithische Höhlenbilder und einige Aspekte ihrer Interpretation. Jahrbuch des Römisch-Germanischen Zentralmuseums Mainz 38, 1991 (1995): 17-31.

PŁonka, T. 2003. The portable art of Mesolithic Europe. Wrockaw: University of Wrockaw Press.

Reimer, P.J., E. Bard, A. Bayliss, J.W. Beck, P.G. Blackwell, C. Bronk Ramsey, C.E. Buck, H. Cheng, R.L. Edwards, M. Friedrich, P.M. Grootes, T.P. Guilderson, H. Haflidason, I. Hajdas, C. Hatté, T.J. Heaton, D.L. Hoffmann, A.G. Hogg, K.A. Hughen, K.F. Kaiser, B. Kromer, S.W. Manning, M. NiU, R.W. Reimer, D.A. Richards, E.M. Scott, J.R. Southon, R.A. Staff, C.S.M. Turney \& J. van Der Plicht. 2013. IntCal13 and Marine13 radiocarbon age calibration curves $0-50,000$ years cal BP. Radiocarbon 55: 1869-87. https://doi.org/10.2458/azu_js_rc.55.16947

Savchenko, S.N. 1999. The history of formation of the collection of Shigir antiquities in Sverdlovsk regional museum, in 120 years of archaeology of the eastern slope of the Urals: from the history of the Urals archaeology. The spiritual culture of the Urals: 46-53. Yekaterinburg: Urals State University.

Savchenko, S.N. \& M.G. Zhilin. 2004. About new details of the big Shigir idol, in The fourth readings in the memory of Bers: 130-35. Yekaterinburg: Aqua.

ŠčELINSKIJ, V.E. \& V.N. ŠIROKOV. 1999. Kapova und Ignatievka: die altsteinzeitlichen Bilderhöhlen im Ural (Thorbecke Speläo 5). Sigmaringen: Thorbecke.

Schmidt, K. 2007. Die Steinkreise und die Reliefs des Göbekli Tepe, in Badisches Landesmuseum Karlsruhe (ed.) Vor 12.000 Jahren in Anatolien. Die ältesten Monumente der Menschheit: 83-96. Karlsruhe: Konrad Theiss.
Serikov, Y.B. 2000. The Paleolithic and Mesolithic of the Middle Eastern Urals. Nizhnii Tagil: Nizhnii Tagil Social-Pedagogical Academy (in Russian).

Tusa, S., G. di Maida, A. Pastoors, H. Piezonka, G.-Ch. Weniger \& T. Terberger. 2013. The Grotta di Cala dei Genovesi-new studies on the Ice Age cave art on Sicily. Prähistorische Zeitschrift 88: 1-22. https://doi.org/10.1515/pz-2013-0001

ShiYATOv, S.G. n.d.. International tree ring database. Available at: www.ncdc.noaa.gov/paleo-search/study/4766 (accessed 12 March 2018).

Veil, St. \& T. Terberger. 2009. Kunst und Umwelt im Wandel, in D. Planck, J. Heiligmann \& N.J. Conard (ed.) Eiszeit: Kunst und Kultur: 347-51. Ostfildern: Thorbecke.

Zaretskaya, N.E., N.K. Panova, M.G. Zhilin, T.G. Antipina, O.N. Uspenskaya \& S.N. Savchenko. 2014. Geochronology, stratigraphy, and evolution of Middle Uralian peatlands during the Holocene (exemplified by the Shigir and Gorbunovo peat bogs). Stratigraphy and Geological Correlation 22: 632-54. https://doi.org/10.1134/S0869593814060082

Zhilin, M.G. 2007. The Early Mesolithic of the Upper Volga: selected problems, in M. Masojć, T. Płonka, B. Ginter \& K. Kozłowski (ed.) Contributions to the Central European Stone Age: 89-104. Wrocław: Institute of Archaeology, University of Wrocław.

- 2010. Mesolithic zoomorphic perforated antler staff heads from central Russia and Eastern Urals: ceremonial weapons or shaman's staves?, in A. Legrand-Pineau \& I. Sidéra (ed.) Ancient and modern bone artefacts from America to Russia: cultural, technological and functional signature (British Archaeological Reports International series 2136): 135-40. Oxford: Archaeopress.

Zhilin, M.G. \& S. Savchenko. 2010. A 'hoard' of bone arrowheads from the site Beregovaya II in Eastern Urals area, in O.M. Davudov (ed.) Problems of archaeology of Eurasia: 302-15. Makhachkala: Dagestan Branch of the Academy of Sciences of the USSR (in Russian).

Zhilin, M.G., S.N. Savchenko, E.A. Nikulina, U. Schmölcke, S. Hartz \& T. Terberger. 2014. Eleven bone arrowheads and a dog coprolite-the Mesolithic site of Beregovaya 2, Urals region (Russia). Quartär 61: 165-87.

Zhilin, M.G., L.L. Kosinskaya \& S.N. Savchenko. 2017. Stone tools for chopping in the Mesolithic of the Middle Trans-Urals (with particular reference to the materials of the Gorbunovski peat bog sites). Stratum plus 2017(1): 271-90.

Received: 10 April 2017; Accepted: 11 July 2017; Revised: 1 September 2017

(C) Antiquity Publications Ltd, 2018 